\title{
Immunohistochemical findings in jejunal specimens from patients with IgA deficiency
}

\author{
T Klemola, E Savilahti, A Arato, T Örmälä, J Partanen, C Eland, S Koskimies
}

\begin{abstract}
Jejunal biopsy specimens from 25 patients with IgA deficiency (IgAd) were studied immunohistochemically to find markers of inflammation. Five of the 25 patients had coeliac disease (CD): they were on a gluten free diet and had normal jejunal morphology. Only two of 15 specimens from control subjects had $\mathrm{CD}^{2} 5^{+}$cells in the surface epithelium, while this was seen in 19 out of 20 specimens from IgAd patients $(p<0 \cdot 0001)$. A significant increase of $\mathrm{CD}^{+} 5^{+}$cells was also noted in the lamina propria of IgAd patients. The median percentage of crypt cells in mitosis $\left(\mathrm{Ki67}^{+}\right.$ cells) was higher in the specimens from IgAd patients $(26 \%)$ than in those from controls $(13 \%, p<0.001)$. The densities of $\gamma \delta \mathrm{T}$ cell receptor positive cells in the surface epithelium and lamina propria did not differ in the specimens from IgAd patients and those of controls nor was the expression of HLA class II antigens augmented in the surface epithelium. These findings were similar for the IgAd patients whether or not the patient had DQB 0201 allele, a genetic marker which is strongly associated with CD. The inadequacy of the local immunoglobulins in patients with IgAd may lead to increased $T$ cell activation, which is accompanied by the appearance of intraepithelial $\mathrm{CD}_{25}{ }^{+}$ cells and with an increase in the mitotic rate in the crypts.

(Gut 1995; 37: 519-523)
\end{abstract}

Keywords: IgA deficiency, coeliac disease, jejunal mucosa, HLA class II antigens, $\gamma \delta \mathrm{T}$ cell receptor

Children's Hospital, University of Helsinki, Helsinki, Finland T Klemola E Savilahti

A Arato

T Örmälä

Finnish Red Cross Blood Transfusion Service, Helsinki, Finland

J Partanen

J Eland

$S$ Koskimies

Correspondence to: Dr T Klemola, Children's Hospital, University of Helsinki, Stenbäckinkatu 11 Fin 00290, Helsinki, Finland.

Accepted for publication 31 January 1995 activation. Gut permeability to foreign proteins is increased in IgAd patients. They often have high titres of milk antibodies, ${ }^{34}$ and excessive uptake of dietary antigens into the circulation has been reported. ${ }^{45}$ We studied jejunal biopsy specimens from patients with IgAd to find if the inadequacy of mucosal antibodies in these patients causes changes in the expression of $T$ cell activation markers in jejunal mucosa.

Asymptomatic coeliac disease (CD) is often found among patients with IgA deficiency (IgAd) - the frequency of CD in these patients is about $10 \%{ }^{6} \mathrm{~A}$ strong association has been found between IgAd and the HLA DQB 0201 gene. ${ }^{7}$ HLA associated susceptibility to develop $\mathrm{CD}$ is primarily conferred by HLA DQ $\left(\alpha 1^{\star} 0501, \beta 1^{\star} 0201\right)$ heterodimer coded by the DQA 0501 and DQB 0201 genes. ${ }^{89}$ An increase in the density of lymphocytes bearing $\gamma \delta \mathrm{T}$ cell receptor $\left(\gamma \delta \mathrm{TCR}^{+}\right), \alpha \beta \mathrm{T}$ cell receptor $\left(\alpha \beta \mathrm{TCR}^{+}\right)$, and enhanced expression of HLA class II antigens DR and DP in the jejunal epithelium are typical of CD. ${ }^{10-18}$ The intestinal specimens of some family members of $C D$ patients may also display similar changes. ${ }^{17} 19$ Among them, the changes are associated with the occurrence of genetic markers of CD. ${ }^{17} 19$

Jejunal biopsy specimens from patients with IgAd were studied to test if the inflammation typical of CD was present in the jejunal mucosa of patients with IgAd but normal jejunal mucosa. We wished to see if the intestine of those patients with IgAd who had inherited the CD marker HLA DQB 0201 differed from that IgAd patients without that gene.

\section{Methods}

PATIENTS

Jejunal biopsy was performed on all patients with IgAd because of the increased risk of CD. In this study jejunal biopsy specimens from 25 patients with IgAd (10 girls and 15 boys, mean age 9.8 years) were studied. Twenty of these patients had a normal jejunal structure while eating normal, gluten containing diet but five patients had CD. This had been diagnosed before the study and these patients were on a gluten free diet. Their jejunal morphology was normal at the time the jejunal biopsy was taken for this study.

Control group specimens were made up as follows: 14 specimens from patients with normal serum IgA and normal intestine (six girls and nine boys, mean age 8.6 years); and 11 from patients with $C D$ and a normal serum IgA value (six girls and five boys, mean age 11.5 years). All CD patients were on a gluten free diet and the morphology of their jejunal specimens was normal.
HLA TYPING

DQB1 alleles were determined using oligonucleotide hybridisation techniques according to the 11 th HLA Workshop. ${ }^{20}$ 
Frequencies of $D Q B 0201$ and $D Q B 0501$ positive IgAd patients and controls

\begin{tabular}{lcll}
\hline Allele & $\begin{array}{l}\text { OgAd patients } \\
(n=15)\end{array}$ & $\begin{array}{l}\text { Controls } \\
(n=95)\end{array}$ & $\begin{array}{l}p \\
\text { (Fischer) }\end{array}$ \\
\hline DQB 0201 & $8 / 15(53 \%)$ & $23 / 95(24 \%)$ & $0 \cdot 17$ \\
DQB 0501 & $8 / 15(53 \%)$ & $30.95(32 \%)$ & $0 \cdot 12$ \\
DQB 0201, or 0501 & $15 / 15(100 \%)$ & $51 / 95(53 \%)$ & $0 \cdot 03$ \\
\hline
\end{tabular}

IMMUNOHISTOCHEMISTRY

Processing the intestinal specimens

The biopsy specimens were immediately embedded in OCT compound and stored at $-70^{\circ} \mathrm{C}$. Serial cryostat sections were cut at 5 $\mu \mathrm{m}$, fixed in acetone for 10 minutes, then in chloroform for 30 minutes, and washed three times in Tris buffer, $\mathrm{pH} 7 \cdot 4$.

\section{Immunohistochemical staining}

The buffer was removed and the sections were covered with the diluted monoclonal antibody $(\mathrm{mAb})$ in Tris buffer for one hour. Endogenous peroxidase was blocked by incubation in $0.5 \%$ peroxidase for 30 minutes. A Vectastain Elite AB kit (PK-6102, Vectro Laboratories, Burlinmghame, CA, USA) was used to stain $\mathrm{mAb}$. Interleukin 2 receptor (CD25) was stained by triple incubation of the monoclonal antibody and alkaline phosphatase-antialkaline phosphatase antiserum. The phosphatase was visualised with a fast red reagent. ${ }^{19}$ Positively stained cells were counted with a light microscope at $900 \times$ magnification.

$M A b$, intestinal specimens

Monoclonal antibody TCR $\delta$ ( $T$ cell Sciences, Cambridge, MA, USA) that recognises a constant region of the $\delta$ chain of T cell receptor and all $\gamma \delta \mathrm{T}$ cells, and antibody $\beta \mathrm{F} 1$ ( $\mathrm{T}$ cell Sciences) which react with nearly all $\alpha \beta \mathrm{T}$ cell receptor ( $\alpha \beta$ TCR) molecules were used at a dilution of $1: 100$. Also used was mAbs against the following lymphocyte surface antigens: CD3 (Anti-Leu4, Becton Dickinson, Mountain View, CA, USA), CD4 (anti-T4, Coulter Immunology Hialeh FL), and CD8 (OKT8, Ortho Diagnostic System, Raritan,

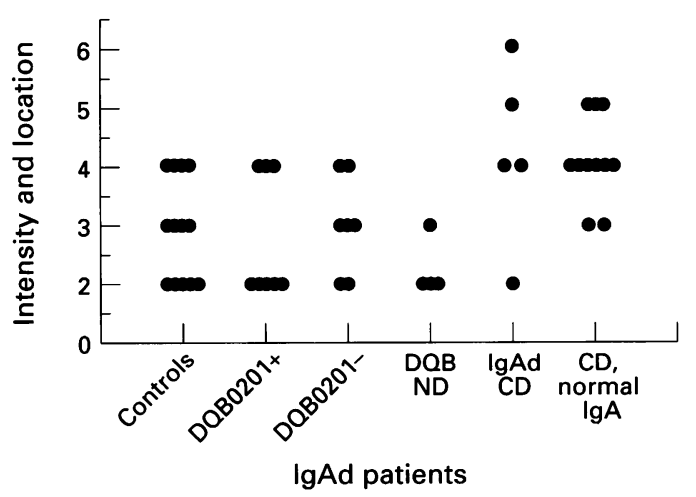

Figure 1: Epithelial staining with anti-HLA-DP antibodies in controls, patients with IgAd having DQB 0201, without it and those in whom the gene analysis was not done (ND). All patients with IgA deficiency (IgAd) and coeliac disease (CD) had DQB 0201. Epithelial staining with class II antibodies was graded from 1 to 6 according to the intensity and cellular distribution and area of staining.
NJ, USA), CD25 (anti-CD25, BectonDickinson). Monoclonal mouse anti-human antibody against proliferating cells (DAKOPC, clone Ki67) was used to detect dividing cells $\left(\mathrm{Ki} 67^{+}\right)$. Monoclonal antibodies to constant fragments of HLA class II antigens, HLA-DR, and HLA-DP were products of Becton-Dickinson and anti-HLA-DQ mAb was a product of Serotec Ltd, Oxford, England.

\section{STATISTICAL ANALYSIS}

The densities of cell staining in the jejunal specimens from patients and controls were compared using the two tailed Mann-Whitney $\mathrm{U}$ test. Epithelial staining with HLA class II antibodies was graded from 1 to 6 according to the intensity ( 0 to 3 ) and cellular distribution (0 to 3, apical membranes - all cell membranes) and the area of staining (parts of the villi and crypts). Fisher's exact test of probability was used to determine the differences in HLA-DR and HLA-DP expression of epithelial cells. The statistical significance of differences in the DQB frequencies was evaluated by Fisher's exact test. To avoid comparisons between populations of unequal sizes, the actual calculations were carried out between the patient group $(n=19)$ and a control subgroup of 30 individuals which was obtained after randomisation of the original control group consisting of 95 unselected Finnish individuals.

ETHICS

The study protocol was reviewed and approved by the Ethical Committee of the Children's Hospital, University of Helsinki.

\section{Results}

DQB ALLELES IN PATIENTS WITH IGAD

DQB alleles could be determined in 19 patients with IgAd. Four of these had CD and they all had the DQB 0201 allele. The remaining 15 had IgAd only. Fifty three per cent (8/15) of them had the DQB 0201 allele. The frequency of DQB 0201 in the unselected Finnish control population was lower $(24 \% ; 23 / 95)$, but the difference was not statistically significant. In addition, DQB 0501 was found in 53\% (8/15) of the patients with IgAd only - but again comparison with the control population $(32 \%$; $30 / 95$ ) showed that this was not significant.

All patients with IgAd (19/19) were positive for DQB 0201 or DQB 0501 compared with only $54 \%(51 / 95)$ in the controls $(p=0.003$ after randomisation). As both the DQB alleles 0201 and 0501 carry 'non-Asp' at position 57, all patients were 'non-Asp' carriers, while $76 \%$ (72/95) of controls were 'non-Asp' carriers. The difference in the frequency of 'non-Asp' carriers, however, is statistically non-significant $(p=0 \cdot 18$ after randomisation)

STAINING WITH HLA CLASS II ANTIBODIES Epithelial staining with anti-HLA-DR and 

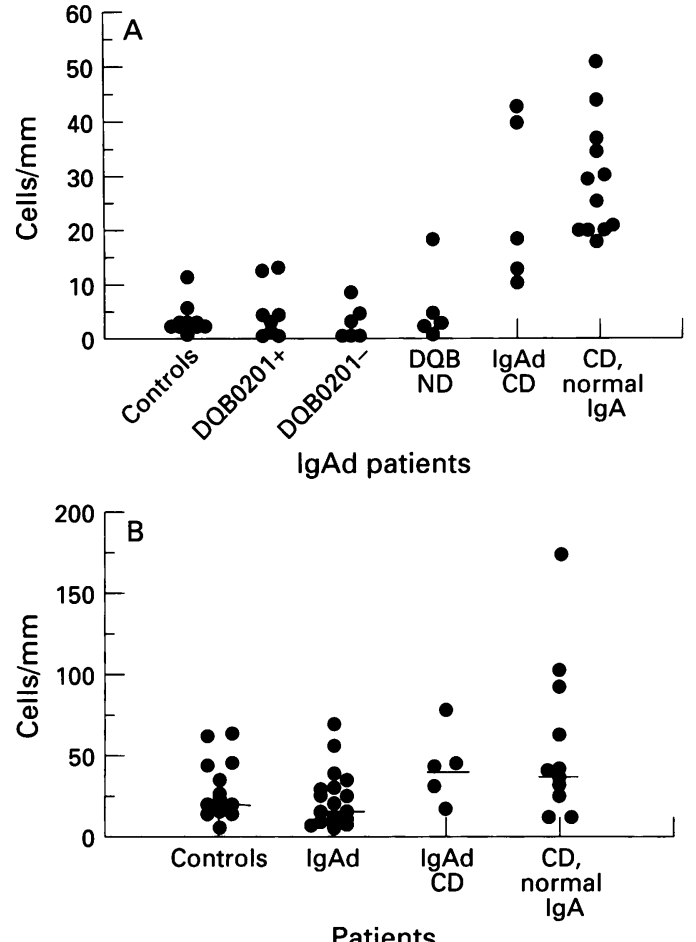

Figure 2: Densities of $\gamma \delta T$ cell receptor (TCR) positive $(A)$ and $\alpha \beta T C R$ positive $(B)$ cells in the surface epithelium of jejunal biopsy specimens from patients with IgA deficiency (IgAd) and controls expressed as cells $/ \mathrm{mm}$. $M e d i a n s$ are represented by solid lines $(B)$. For the densities of $\gamma \delta T C R$ positive cells the patients with IgAd are divided on the basis of the occurrence of $D Q B 0201$ gene as in Figure 1.

anti-HLA-DP was similar in patients with IgAd without $C D$ and controls (Fig 1). Staining in specimens from IgAd patients with the DQB 0201 gene did not differ from that in IgAd patients without the DQB 0201 gene. The expression of HLA-DP was augmented in the jejunal epithelium of the patients with $C D$ and $\operatorname{IgAd}(p<0.05)$ and in the $C D$ patients with normal IgA $(p<0.005)$ (Fig 1). Positive staining of epithelial cells with DQ antibody was present in five specimens from IgAd patients and in two control specimens but the difference was not statistically significant. The densities of HLA-DR, HLA-DP, and HLADQ-positive cells in the lamina propria did not differ in IgAd patients and controls (data not shown).

T CELLS, $\gamma \delta \mathrm{TCR}^{+}$AND $\alpha \beta \mathrm{TCR}^{+}$CELLS

Densities of $\mathrm{CD}^{+}, \mathrm{CD}^{+}$, and $\mathrm{CD}^{+}$cells in the surface epithelium and lamina propria did not differ in the patient groups and controls (data not shown). Similar densities of $\alpha \beta \mathrm{TCR}^{+}$and $\gamma \delta \mathrm{TCR}^{+}$cells were present in the surface epithelium (Fig 2) and lamina propria (data not shown) of jejunal biopsy specimens from IgAd patients without CD and controls. Those with or without the DQB 0201 gene had similar densities of $\gamma \delta \mathrm{TCR}^{+}$ cells in the epithelium (Fig 2A). IgAd patients with $C D$ on a gluten free diet had significant higher densities $(p<0.0001)$ of $\gamma \delta \mathrm{TCR}^{+}$ cells in the jejunal surface epithelium (Fig 2B).
INTERLEUKIN 2 RECEPTOR (CD25) BEARING CELLS IN THE LAMINA PROPRIA AND IN THE SURFACE EPITHELIUM

Patients with IgAd had more $\mathrm{CD} 25^{+}$cells in the lamina propria $(p<0.002)$ (Fig 3$)$ and in the surface epithelium of jejunal mucosa $(p<0.0001)$ (Fig 3) than the controls. The increase in $\mathrm{CD} 25^{+}$cells was not associated with the occurrence of the DQB 0201 gene. IgAd patients with or without this gene had similar densities of these cells in the epithelium and lamina propria (data not shown). Nor was the increase associated with $\mathrm{CD}$ - the increase was present only in IgAd coeliac and not in coeliac with normal IgA level (Fig 3).

Ki67 ${ }^{+}$CELLS IN THE CRYPT EPITHELIUM

The percentage of dividing, $\mathrm{Ki} 67^{+}$cells was increased in the jejunal crypt epithelium in specimens from IgAd patients $(p<0.001 v$ controls) (Fig 4). This increase was not associated with the occurrence of $\mathrm{CD}$ associated DQB genes in IgAd patients with normal jejunum (data not shown). Specimens from CD patients on a gluten free diet had the same percentage of $\mathrm{Ki} 67^{+}$cells in the crypts as the controls, while IgAd patients with $C D$ had similar percentages as IgAd patients with a normal jejunum.

\section{Discussion}

Secretion of IgA is the most important defence mechanism of the mucosal surfaces against microbial infections and the penetration of foreign proteins. In patients with selective IgA deficiency, this secretion is severely diminished or lacking and is replaced by an excessive
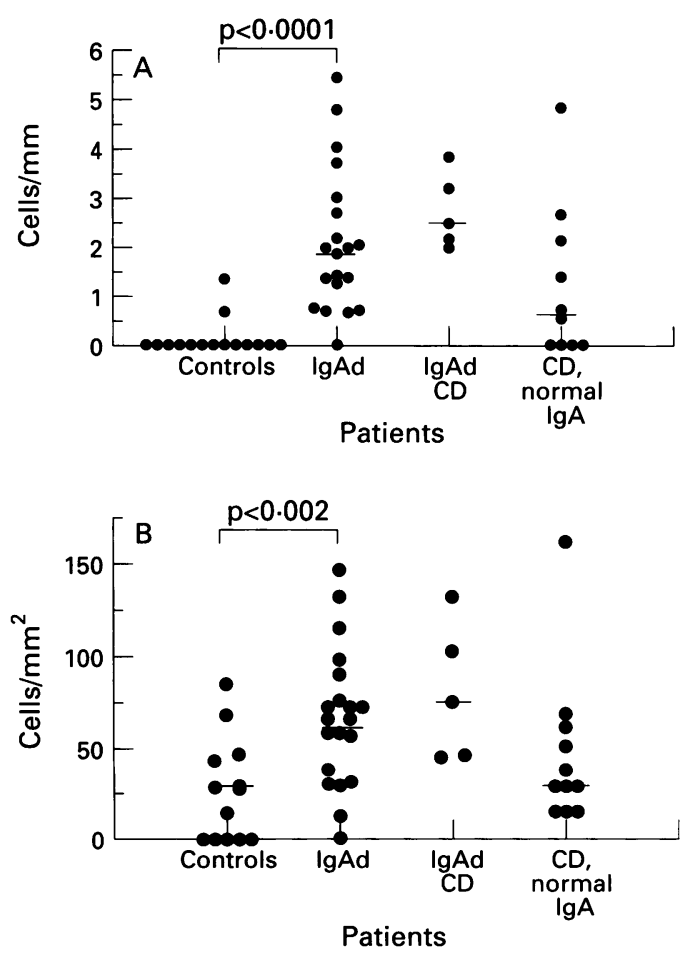

Figure 3: Interleukin 2 receptor bearing $\left(C D 25^{+}\right)$cells in the surface epithelium (cells/mm) (A) and in the lamina propria $\left(\right.$ cells $\left./ \mathrm{mm}^{2}\right)$ (B) of jejunal mucosa in IgAd patients and controls. Symbols as in Figure 2. 


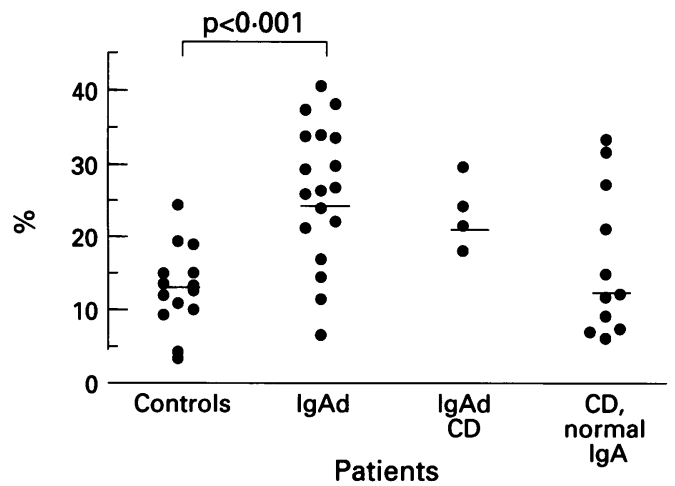

Figure 4: Dividing $\mathrm{Ki67}^{+}$cells in the jejunal crypt epithelium (expressed as percentage of positive cells) in specimens from IgAd patients, controls and coeliac disease (CD) patients. Symbols as in Figure 2.

secretion of $\operatorname{IgM}^{2122}$ and the presence of an increased density of IgM secreting cells in the jejunum. ${ }^{23}$ Intestinal diseases are common among IgAd patients and some of them also have minimal morphological changes in the jejunal mucosa. ${ }^{24}$ In addition, the density of intraepithelial lymphocytes is increased in some patients with IgAd. ${ }^{25} 26$ In our study it was found that the density of activated CD25 $5^{+}$ cells in increased in both the lamina propria and in the surface epithelium in the jejunal mucosa of IgAd patients. Raised serum concentrations of soluble CD8, neopterin, and $\beta_{2}$ microglobulin have been reported in patients with common variable immunodeficiency ${ }^{27} 28$ and in IgAd patients. ${ }^{29}$ It has been suggested that these findings reflect enhanced $T$ cell mediated immunity in these patients. ${ }^{27-29}$ Our results also support the theory that enhanced $\mathrm{T}$ cell activation is present in the intestine of IgAd patients. The $T$ cell activation may be due to increased antigenic stimulation caused by ineffective antigen exclusion or to a chronic infection in the intestinal mucosa of IgAd patients.

In fetal cultured intestine, $T$ cell activation generates total or partial villous atrophy and a profound crypt cell hypertrophy. ${ }^{30}$ The changes are associated with an increase of dividing $\mathrm{Ki} 67^{+}$cells in the cryptal epithelium. These changes are mediated by lamina propria $T$ cells. ${ }^{31}$ The activated $T$ cells secrete interleukin 2 and interferon $\gamma, 3233$ but whether these or other cytokines generate the proliferation of crypt cells is still unknown. ${ }^{32}$ Activated $T$ cells have been found in the lamina propria of jejunal specimens from CD patients. ${ }^{33}$ These cells were present in a higher density in both the lamina propria and epithelium of patients with IgAd compared with controls, indicating $T$ cell activation in the intestine of patients with IgAd. The increase in percentage of dividing $\mathrm{Ki} 67^{+}$cells in the crypt epithelium of IgAd patients may be due to this $T$ cell activation in the lamina propria.

Nilssen et al $^{29}$ found an increased density of $\gamma \delta \mathrm{TCR}^{+}$intraepithelial lymphocytes in the jejunal mucosa in a patient with IgAd and overt partial villous atrophy, and it was suggested that this may reflect a compensatory mechanism of surface protection in patients with
IgAd and a low frequency of infection. In our study a constant increase in $\gamma \delta \mathrm{TCR}^{+}$intraepithelial lymphocytes was found only in the jejunum of patients with IgAd and CD during gluten free diet when their jejunal morphology was normal. In contrast, all IgAd patients with normal jejunum eating a normal, gluten containing diet had a density of $\gamma \delta \mathrm{TCR}^{+}$cells similar to immunologically normal controls.

Increased density of $\gamma \delta \mathrm{TCR}^{+}$cells and $\mathrm{CD}^{2} 5^{+}$in the jejunal epithelium, and augmented epithelial expression of HLA-DR and HLA-DP antigens were found in a patient with normal jejunal mucosa, who later developed typical CD. ${ }^{34}$ These findings also occurred together with $\mathrm{CD}$ marker $\mathrm{DQ}$ genes in relatives of CD patients. ${ }^{17} 19$ These patients are thought to show latent $\mathrm{CD}$ and are at an appreciably increased risk of developing CD. ${ }^{17} 1934$ The incidence of CD among IgAd patients is about $10 \%{ }^{1}$ HLA class II gene 0201, which is strongly associated with $\mathrm{CD},{ }^{89}$ was present in all of the IgAd CD patients in our study, confirming that these patients are genetically similar to CD patients with normal IgA levels. Recently, Olerup et al reported that amino acids other than aspartic acid ('non-Asp') at position 57 of DQB are strongly associated with IgA deficiency. ${ }^{7}$ Our results are similar to those of Olerup et al, although the difference in the frequency of 'non-Asp' carriers was statistically non-significant in our study.

According to the present study, emerging, latent $C D$ found in relatives of $C D$ patients ${ }^{17} 19$ does not exist, or is rare, among IgAd patients with a normal intestine. The staining of epithelial cells with HLA class II antigens and the densities of $\alpha \beta T C R^{+}$- and $\gamma \delta \mathrm{TCR}^{+}$cells were similar in the IgAd patients with normal jejunum and the controls, and immunohistochemical findings typical of CD were absent from the intestine of even those IgAd patients with normal jejunum who had CD marker DQB 0201. However, IgAd patients had more CD25+ cells in both the epithelium and lamina propria of the jejunum, and the proportion of crypt cells in mitosis was greater than in the controls. These changes were not associated with the CD marker allele DQB 0201. Patients with and without the DQB 0201 allele had similar densities of $\mathrm{CD}_{2} 5^{+}$and $\mathrm{Ki} 67^{+}$cells.

This work was supported by grants from the Sigrid Juselius foundation and the University of Helsinki.

1 Savilahti E, Klemola T, Hovi T, Mellander L, Stenvik M, Hovi T. Inadequacy of mucosal IgM antibodies in selective IgA deficiency: excretion of attenuated polio vaccine tive IgA deficiency: excretion of attenuated polio vaccin

2 Friman V, Quiding M, Czerkinsky C, Nordström I, Larsson L, Ericson D, et al. Intestinal and circulating antibodyforming cells in IgA-deficient individuals after cholera vaccination. Clin Exp Immunol 1994; 95: 222-6.

3 Buckley RH, Dees SC. Correlation of milk precipitins with IgA deficiency. $N$ Engl $\mathcal{F}$ Med 1969; 281: 465-9.

4 Cunningham-Rundles C, Brandeis WE, Good RA, Day NB. Milk precipitins, circulating immune complexes and IgA deficiency. Proc Nat Assoc Sci USA 1978; 75: 3387-9. 5 Cunningham-Rundles C, Brandeis WE, Day NB. Bovine antigens and the formation of circulating immune complexes in selective immunoglobulin A deficiency. ¥ Clin Invest 1979; 64: 272-9.

6 Savilahti E, Pelkonen P, Verkasalo M, Koskimies S Selective deficiency of immunoglobulin A. Klin Pädiatr 1985; 197: 336-40. 
7 Olerup O, Smith CIE, Hammarström L. Different amino acids at position 57 of the HLA DQ $\beta$ chain associated with susceptibility and resistance to IgA deficiency. Nature with susceptibility and

8 Sollid LM, Markussen G, Ek J, Gjerde H, Vardal F, Thorsby E. Evidence for primary association of celiac disease to a particular HLA DQ $\alpha / \beta$ heterodimer. $\mathcal{f}$ Exp Med 1989; 169: 345-50.

9 Roep BO, Bontrop RE, Pena AS, van Eggermond MCJA, van Rood J, Giphart MJ. An HLA-DQ alpha allele identified at DNA and protein level is strongly associated with coeliac disease. Human Immunol 1988; 23: 271-9.

10 Savilahti E, Arato A, Verkasalo M. Intestinal $\gamma / \delta$ beating T lymphocytes in coeliac disease and inflammatory bowel disease in children. Constant increase in coeliac disease. Pediatr Res 1990; 28: 579-81.

11 Scott H, Brandtzaeg P, Solheim BG, Thorsby E. Relations between HLA-DR-like antigens and secretory component (SC) in jejunal epithelium of patients with coeliac disease or dermatitis herpetiformis. Clin Exp Immunol 1981; 44: 233-8

12 Arnaud-Battandier F, Cerf-Bensussan N, Amsellen R, Schmitz J. Increased HLA-DR expression by enterocytes in children with coeliac disease. Gastroenterology 1986; 91: 1206-12.

13 Marley NJ, Macartney JC, Ciclitira PJ. HLA-DR, DP and $\mathrm{DQ}$ expression in the small intestine of patients with coeliac disease. Clin Exp Immunol 1987; 70: 386-93.

14 Spencer J, Isaacson PG, Diss TC, MacDonald TT. Expression of disulfide-linked and non-disulfide-linked Expression of disulfide-linked and non-disulfide-linked
forms of the $\mathrm{T}$ cell receptor $\gamma \delta$ heterodimer in human forms of the $\mathrm{T}$ cell receptor $\gamma \delta$ heterodimer in human
intestinal intraepithelial lymphocytes. Eur $\mathcal{f}$ Immunol intestinal intraepithe

15 Halstensen TS, Scott H, Brandtzaeg T. Intraepithelial T cells of TCR $\gamma \delta^{+} \mathrm{CD} 8^{-}$and $\mathrm{V} \delta 1 / \mathrm{J} \delta 1^{+}$phenotypes are increased in coeliac disease. Scand $\mathcal{F}$ Immunol 1989; 30: 665-72.

16 Russell GJ, Winter HS, Fox VL, Bhan AK. Lymphocytes bearing the $\gamma / \delta \mathrm{T}$-cell receptor in normal human intestine and coeliac disease. Hum Pathol 1991; 22: 690-4.

17 Holm K, Mäki M, Savilahti E, Lipsanen V, Laippala P, Koskimies S. Intraepithelial $\gamma \delta \mathrm{T}$-cell-receptor lymphocytes and genetic susceptibility to coeliac disease. Lancet 1992; 339: 1500-3.

18 Kutlu T, Brousse N, Rambaud C, Le Deist F, Schmitz J, Gerf-Bensussan N. Numbers of T cell receptor (TCR) $\alpha \beta+$ but not of TCR $\gamma \delta+$ intrapithelial lymphocytes correlate with the grade of villous atrophy in coeliac patients on a long term normal diet. Gut 1993; 34: 208-14.

19 Holm K, Savilahti E, Koskimies S, Mäki M. Immunohistochemical changes in the jejunum in first degree relatives if patients with coeliac disease and coeliac market DQ genes. HLA class II antigen expression, interleukin-2 receptor positive cells and dividing crypt cells. Gut 1994; 35: 55-60.

20 Kimura A, Sasazuki T. Eleventh International Histocompatibility Workshop reference protocol for the Histocompatibility Workshop reference protocol for the
HLA DNA-typing technique. In: T Sasazuki, ed. $H L A$
1991. Vol 1. Oxford: Oxford University Press, 1992: 397-425.

21 Brandtzaeg P, Gjeruldsen ST, Korsud F, Baklien K, Berdal $\mathrm{P}, \mathrm{Ek} \mathrm{J}$. The human secretory immune system shows striking heterogeneity with regard to involvement of J chain-positive IgD immunocytes. F Immunol 1979; 122: 503-10.

22 Brandtzaeg P, Fjellander I, Geruldsen ST. Immunoglobulin M: local synthesis and secretion in patients with immunoglobulin A deficiency. Science 1968; 160: 789-91.

23 Savilahti E. IgA deficiency in children. Immunoglobulincontaining cells in the intestinal mucosa, immunoglobulins in secretions and serum IgA levels. Clin Exp Immunol 1973; 13: 395-406.

24 Giorgi PL, Catassi C, Sbarbati A, Bearsi J, Cinti S. Ultrastructural findings in the jejunal mucosa of children with IgA deficiency. $\mathcal{F}$ Pediatr Gastroenterol Nutr 1986; 5: with Ig

25 Klemola T. Immunohistochemical findings in the jejunum of IgA-deficient persons: Number of intraepithelial T lymphocytes is increased. $\mathcal{F}$ Ped Gastroenterol Nutr 1988; 7: 537-43.

26 Savilahti E, Mäki M, Holm K, Lipsanen V, Reunala T, Klemola T. Immunological markers of latent coeliac disease. In: Auricchio S, Visakorpi J, eds. Common food intolerances 1: Epidemiology of coeliac disease. Vol 2. Basel: Karger, Dynamic Nutrition Research. 1992; 128-41.

27 North ME, Spickett GP, Webster ADB. Raised serum CD8, CD25 and $\beta_{2}$-microglobulin in common variable immunodeficiency. Clin Exp Immunol 1991; 86: 252-55.

28 Aukrust P, Froland SS, Muller F. Raised serum neopterin levels in patients with primary hypogammaglobulinemia; correlation to other immunological parameters and to clinical and histological features. Clin Exp Immunol 1992; 89: $211-6$.

29 Nilssen DE, Aukrust P, Froland SS, Muller F, Fausa O, Halstensen TS, Brandtzaeg P. Duodenal intraepithelial $\gamma / \delta \mathrm{T}$ cells and soluble CD8, neopterin and $\beta 2-$ microglobulin in serum of IgA-deficient subjects with or without IgG subclass deficiency. Clin Exp Immunol 1993; 94: 91-8.

30 MacDonald TT, Spencer J. Evidence that activated mucosal $T$ cells plays a role in the pathogenesis of enteropathy in human small intestine. $f$ Exp Med 1988; enteropathy in

31 MacDonald TT. The role of activated T lymphocytes in gastrointestinal disease. Clin Exp Allergy 1990; 20: 247-52.

32 MacDonald TT, Spencer J. Cell-mediated injury in the intestine. Gastroenterol Clin North Am 1992; 21: 367-86.

33 Kelly J, O'Farrelly C, O'Mahony C, Weir DG, Feighery C. Immunoperoxidase demonstration of the cellular composition of the normal and coeliac small bowel. Clin Exp Immunol 1987; 68: 177-88.

34 Mäki M, Holm K, Collin P, Savilahti E. Increase of gamma/delta $\mathrm{T}$ cell receptor bearing lymphocytes in normal small bowel mucosa in latent coeliac disease. Gut 1991; 32: 1412-4. 